\title{
Effects of a predatory fish on the recruitment and abundance of Caribbean coral reef fishes
}

\author{
Jim Beets* \\ University of Richmond, Department of Biology, Richmond, Virginia 23173, USA
}

\begin{abstract}
The importance of postrecruitment factors in determining assemblage structure of coral reef $f_{1}$ shes is one of the most controversial topics in community ecology. To document the effects of predation on postlarval recruitment and the abundance of resident reef fishes, I manipulated small piscivorous fish on 12 model patch reefs located in uniform seagrass habitat in the U.S. Virgin Islands. Six reefs served as controls and 6 were used for predator removals. Weekly censuses were conducted for 2 mo before and after predator manipulations to document effects of removals. Removals of the squirrelfish Holocentrus adscensionis had a significant effect on the recruitment and abundance of other species. During the first removal experiment, which was conducted during a peak recruitment period, high densities of squirrelfish depressed postlarval recruitment and juvenile abundance of grunts Haemulon spp., the most abundant species on the reefs. Following peak recruitment of grunts, a second squirrelfish removal resulted in increases in juvenile grunt abundance on predator-removal reefs. These results indicate the importance of postrecruitment factors, particularly predation, in structuring assemblages of coral reef fishes at a small spatial scale.
\end{abstract}

KEY WORDS: Assemblage structure Predation Recruitment Caribbean Coral reef fishes

\section{INTRODUCTION}

Our understanding of the structure of many aquatic and terrestrial ecological communities has advanced considerably during the past 2 decades (Connell 1983, Sousa 1984, Strong et al. 1984). The influence of basic processes, such as competition, predation, and disturbance, on community structure has been welldocumented (Connell 1983, Sousa 1984, Sih et al. 1985, Kerfoot \& Sih 1987). In contrast, progress in delimiting processes affecting coral reef fish assemblage structure has been relatively slow. Intrinsic factors which influenced this slower pace include difficulties in sampling and observation, great diversity, problematic taxonomy, and large differences in life history characteristics among assemblage components. Also, as pointed out by Sale (1991), it has been necessary to overcome a large bias, namely the generally accepted speculation that tropical ecosystems were stable.

•E-mail: jbeets@richmond.edu
During the past decade, evidence of the importance of recruitment variability on coral reef fish assemblages increased (reviewed by Doherty \& Williams 1988, Doherty 1991). Much emphasis was given to recruitment limitation, i.e. fish assemblages are undersaturated due to limited postlarval recruitment (Doherty 1983, Victor 1986, Doherty \& Fowler 1994), and the random events of settlement (Sale \& Douglas 1984, Doherty \& Williams 1988) The fact of recruitment variability is widely recognized, but its effects over a broad range of conditions and various scales are not fully understood (Doherty \& Williams 1988, Doherty 1991, Sale 1991, Williams 1991). Recent investigations on the importance of resource partitioning (reviewed by Ross 1986), competition (reviewed by Jones 1990, 1991), and predation (reviewed by Hixon 1991) have demonstrated that models based on a single process are too narrowly focused. More balanced pluralistic views have recently been presented (Mapstone \& Fowler 1988, Warner \& Hughes 1988, Forrester 1990, Jones 1990, 1991, Hixon 1991, Sale 1991, Hixon \& Beets 1993) 
The importance of postrecruitment processes has been demonstrated at least on small scales (i.e. the size of small patch reefs). Factors affecting settlement, such as social determination (facilitation or inhibition of postlarval settlement by resident fishes), have been demonstrated (Shulman et al. 1983, Sweatman 1983, 1985. Jones 1987, Booth 1991). However, the effect of predation on recruitment and assemblage structure has received less attention (review by Hixon 1991 , Caley 1993, Hixon \& Beets 1993, Carr \& Hixon 1995).

Investigations supporting the importance of predation on postlarval recruits and juveniles of coral reef fishes are uncommon (e.g. Shulman \& Ogden 1987, Hixon \& Beets 1989, 1993, Caley 1993, Carr \& Hixon 1995, Forrester 1995), as are studies of the effects of predators on coral reef fish assemblage structure (reviewed by Hixon 1991). Experimental evidence of the importance of predation has provided varying information. By removing predators on 20 experimental reefs for more than 2 yr, Caley (1993) demonstrated that species richness and abundance of non-piscivorous fishes were greater on removal reefs than on controls although most of the species-level tests were not significant. Using an array of translocated natural patch reefs, Carr \& Hixon (1995) demonstrated increased survivorship of 2 recently recruited species on which resident predators had been removed. Other experimental approaches have provided equivocal conclusions. A few studies presented weak or circumstantial evidence of the effect of predator abundance on prey abundance (Bohnsack 1982, Stimson et al. 1982, Shpigel \& Fishelson 1991). In an exclusion experiment, Doherty \& Sale (1985) demonstrated that exclusion of predators increased the survivorship of some sedentary species, although results were confounded by the additional shelter complexity of exclusion cages. By providing different numbers and sizes of

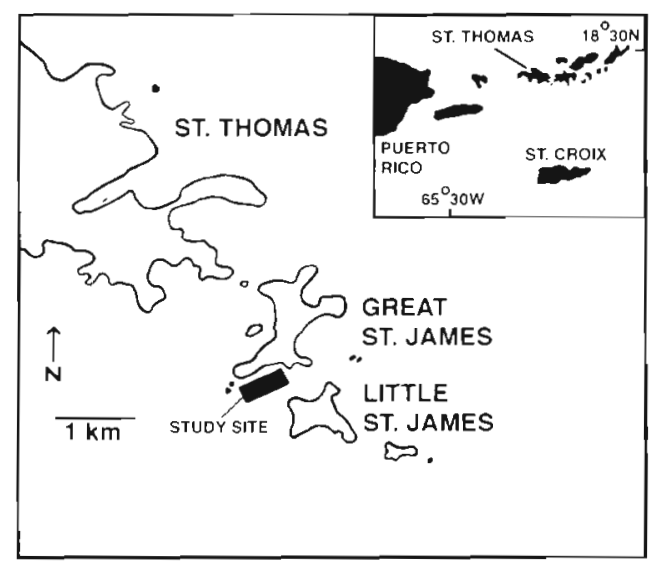

Fig. 1 Location of model reef site (dark rectangle) off St. Thomas, U.S. Virgin Islands shelter space using experimental reefs, Hixon \& Beets (1993) presented evidence that predator abundance had a negative influence on prey abundance and species richness. Hixon (1991) summarized evidence for the importance of predation and the need for testing the relative contribution of predation as a structuring process.

I designed the present study to investigate the influence of small predators on postlarval recruitment and assemblage structure of coral reef fishes. I accomplished this goal by removing small predators from experimental reefs. The primary prediction was that if predation is a major factor affecting local population dynamics, the presence of predators would negatively affect the number of recruits and juvenile fish.

\section{METHODS}

Site description. The model reefs used in this study were located in a shallow-water bay off the southeastern shore of St. Thomas, U.S. Virgin Islands (Fig. 1). The habitat comprised seagrass beds with low density of seagrass plants (predominantly Thalassia testudinum Banks ex Konig with sparse Syringodium filiforme Kutzing) in water depths of 4.5 to $8.0 \mathrm{~m}$. Each reef was placed at least $100 \mathrm{~m}$ from the nearest natural reef and $50 \mathrm{~m}$ from the nearest model reef

Experimental design. Model reefs were used to (1) establish similar fish assemblages among replicates, (2) observe and manipulate replicates of similar history, (3) control habitat variables (reef size, reef structure, relative heterogeneity, adjacent habitat type), and (4) control distance among replicates and from source areas

Several designs of model reets were tested to determine the effects of structure and habitat type on fish assemblage structure. The design selected for model reefs in this investigation was a small patch with high structural complexity. This design yielded fish assemblages with high species richness (relative to reefs with lower structural complexity) dominated by a few abundant species of small fishes $(<10 \mathrm{~cm}$; Beets 1991). In November 1987 , I built 12 replicate reefs, each constructed of 24 cement blocks (each $40 \times 15 \mathrm{~cm}$ ), broken into 10 to $25 \mathrm{~cm}$ pieces and placed in a circular mound less than $0.5 \mathrm{~m}$ in height. I allowed the model reefs to be colonized for at least 6 mo prior to manipulation.

Complete visual censuses of all fishes on each reef were conducted at least once a week for 2 mo before and after manipulations. Two scuba divers approached each reef from opposite sides, slowly circled and recorded the number and sizes of each species within $1 \mathrm{~m}$ of the reef (Sale \& Douglas 1981). Counts were also made of transient species within the area. Sizes (total 
length, TL) of individuals were visually estimated to the nearest $\mathrm{cm}$. Small fishes $(<3 \mathrm{~cm} \mathrm{TL})$ were estimated to the nearest $0.5 \mathrm{~cm}$. Data for each reef were compared following sampling, and few differences in counts were recorded between divers. The complete count for each census included all species and individuals observed.

The predatory species used in this study was the squirrelfish Holocentrus adscensionis. This species colonized reefs in adequate numbers for manipulation ( 8 to 20 individuals per reef). Previous trophic studies have demonstrated that holocentrids are at least occasionally piscivorous (Randall 1967, Gladfelter \& Johnson 1983), and piscivory by these species has been observed directly where small prey fishes were abundant (M. Hixon \& J. Beets unpubl.). I analyzed stomach contents of squirrelfishes taken from nearby artificial reefs $(n=6)$ and observed several small juvenile fishes $(\mathrm{n}=11)$. A few other predators (primarily groupers and snappers) did colonize model and nearby natural reefs in low abundance. I manipulated a few of these species on other reef sets, but their low abundance and low reef fidelity yielded no signficant results.

The reefs were grouped into 2 sets of 6 for separate experiments. For each experiment, treatments were assigned randomly to half the reefs in each set. Two separate removal experiments of Holocentrus adscensionis were conducted: the first during maximum postlarval recruitment in May 1989, and the second following the postlarval recruitment peak in July 1989. Squirrelfish were removed by both divers using handnets. No disturbance or emigration of other fishes was observed during manipulations. During the first removal, 8 to 15 individuals ( 8 to $16 \mathrm{~cm} \mathrm{TL}$ ) of $H$. adscensionis were removed from each of 3 reefs in one set of 6 reefs. One reef was rapidly recolonized by several individuals of $H$. adscensionis which could not be easily removed, and this reef was not included in analysis. During the second removal, 11 to 20 individuals of $H$. adscensionis were removed from each of 3 reefs. All control reefs, except one, had 9 to 16 individuals of $H$. adscensionis which persisted during the experiments. Following the second removal, one control reef experienced rapid emigration of squirrelfishes and was not included in analysis.

Experiments were terminated with the passage of Hurricane Hugo, September 17 to 18,1989 , when all model reefs were destroyed.

Data analysis. Abundance data used in analyses included all species and individuals observed within $1 \mathrm{~m}$ of the reef. I categorized fishes into 1 of 3 categories: (1) new recruits $(<2.0 \mathrm{~cm} . T L),(2)$ residents, fishes which sought shelter during sampling, and (3) transients, such as lizardfishes (Synodontidae), jacks (Carangidae), and goatfishes (Mullidae) (Table 1).
New recruits were not counted as residents and all 3 categories were analyzed separately. Although it could not be determined if recruits had settled directly onto reefs or originally onto surrounding habitat then moved to reefs, fishes smaller than $2.0 \mathrm{~cm}$ long were counted as new recruits if not present on a given reef during the previous census.

I analyzed data on new recruits using repeated measures analysis of variance (ANOVA) following positive assumption tests for normality and homogeneity of variances (Winer 1971). Abundance data $[\ln (x+1)$-transformed] for each reef from 4 censuses each before and after manipulations were used in analyses.

For analysis of abundance data of resident fishes on manipulated and control reefs, I conducted Student's $t$-tests of the differences between the mean abundance of fishes on each reef for 4 censuses before manipulations and 4 censuses after manipulations. Tests for normality and homogeneity of variances were conducted prior to each analysis. I used Spearman rank correlation analyses to investigate possible interaction between species. I averaged species abundance data over 2 mo prior to manipulation for correlation analyses. I conducted statistical analyses using the SYSTAT microcomputer package (Wilkinson 1990).

\section{RESULTS}

\section{General patterns of colonization and recruitment}

Colonization of the small model reefs was rapid, reaching an asymptote in number of species and abundance of individuals within 1 to 3 mo after construction (Beets 1991). Colonization and recruitment did not differ among reef sets, although relative abundance and dominance among species varied among replicates. A total of 65 species were recorded during sampling, excluding large transient species observed greater than $1 \mathrm{~m}$ from reefs such as jacks and barracuda (Table 1). The number of species observed per reef was consistent among sampling periods, ranging between 9 and 16 (Beets 1991).

Although recruitment was variable, recruitment peaks for many species were observed during April to June. Recruitment of the dominant haemulid species varied among months during this study (Fig 2). Tomtate grunt Haemulon aurolineatum, which was often numerically dominant, had the largest recruitment peak during April to June. Recruitment of the second most abundant haemulid, white grunt $H$. plumieri, peaked during January to February. The cottonwick $H$. melanurum was the third most abundant haemulid and showed low and intermittent recruitment. 
Table 1. Mean abundance and classification of species observed during visual censuses of experimental reefs. Mean abundance per reef per census was calculated for 12 reefs during 4 mo of study. Sample standard deviation is given in parentheses. R: resident species; $N$ : species with new recruits on experimental reefs; $T$ : transient species observed within $1 \mathrm{~m}$ of experimental reefs; $\mathrm{X}$ : transient species observed greater than $1 \mathrm{~m}$ from experimental reefs. Scientific names follow Robins et al. (1991)

\begin{tabular}{|c|c|c|}
\hline Species & Abundance & Classification \\
\hline \multicolumn{3}{|l|}{ Rhincodontidae: carpet sharks } \\
\hline Ginglymostoma cirratum (nurse shark) & & $x$ \\
\hline \multicolumn{3}{|l|}{ Dasyatidae: stingrays } \\
\hline Dasyatis americana (southern stingray) & & $x$ \\
\hline \multicolumn{3}{|l|}{ Muraenıdae: morays } \\
\hline Gymnothorax moringa (spotted moray) & $0.12(0.35)$ & $\mathrm{R}$ \\
\hline G. vicinus (purplemouth moray) & $0.21(0.33)$ & $\mathrm{R}$ \\
\hline \multicolumn{3}{|l|}{ Synodontidae: lizardfishes } \\
\hline Synodus intermedius (sand diver) & $0.06(0.12)$ & $T, X$ \\
\hline \multicolumn{3}{|l|}{ Holocentridae: squirrelfishes } \\
\hline Holocentrus adscensionis (squirrelfish) & $5.74(4.65)$ & $\mathrm{R}$ \\
\hline H. coruscus (reef squirrelfish) & $2.57(1.73)$ & $\mathrm{R}$ \\
\hline H. rufus (longspine squirrelfish) & $0.02(0.06)$ & $\mathrm{R}$ \\
\hline Myripristis jacobus (blackbar soldierfish) & $41.16(32.92)$ & $\mathrm{R}$ \\
\hline \multicolumn{3}{|l|}{ Aulostomidae: trumpetfishes } \\
\hline Aulostomus maculatus (trumpetfish) & $0.08(0.24)$ & $\mathrm{T}$ \\
\hline \multicolumn{3}{|l|}{ Serranidae: sea basses } \\
\hline Epinephelus afer (mutton hamlet) & $4.43(2.88)$ & $\mathrm{R}$ \\
\hline E. cruentatus (graysby) & $0.02(0.06)$ & $\mathrm{R}$ \\
\hline E. fulvus (coney) & $0.02(0.06)$ & $\mathrm{R}$ \\
\hline E. guttatus (red hind) & $0.01(0.08)$ & $\mathrm{R}$ \\
\hline Hypoplectrus unicolor (butter hamlet) & $0.01(0.06)$ & $\mathrm{R}$ \\
\hline Mycteroperca interstitialis (yellowmouth grouper) & $0.07(0.17)$ & $\mathrm{R}$ \\
\hline$M$. venenosa (yellowfin grouper) & $0.01(0.06)$ & $R$ \\
\hline Serranus tabacarius (tobaccofish) & $0.05(0.07)$ & $\mathrm{R}$ \\
\hline S. tigrinus (harlequin bass) & $0.19(0.17)$ & $\mathrm{R}$ \\
\hline \multicolumn{3}{|l|}{ Apogonidae: cardinalfishes } \\
\hline Apogon maculatus (flamefish) & $0.02(0.06)$ & $\mathrm{R}$ \\
\hline \multicolumn{3}{|l|}{ Malacanthidae: tilefishes } \\
\hline Malacanthus plumieri (sand tilefish) & & $\mathrm{x}$ \\
\hline \multicolumn{3}{|l|}{ Carangidae: jacks } \\
\hline Caranx bartholomaei (yellow jack) & $0.24(0.58)$ & $T_{1} \mathrm{X}$ \\
\hline C. crysos (blue runner) & & $\mathrm{x}$ \\
\hline C. ruber (bar jack) & & $\mathrm{x}$ \\
\hline \multicolumn{3}{|l|}{ Lutjanidae: snappers } \\
\hline Ocyurus chrysurus (yellowtail snapper) & $0.14(0.16)$ & T. $\mathrm{X}$ \\
\hline \multicolumn{3}{|l|}{ Haemulidaae: grunts } \\
\hline Haemulon aurolineatum (tomtate grunt) & $120.81(79.09)$ & $\mathrm{R}, \mathrm{N}$ \\
\hline H. flavolineatum (French grunt) & $0.07(0.08)$ & $R, N$ \\
\hline H. melanurum (cotton wick) & $8.69(9.66)$ & $R, N$ \\
\hline H. plumierl (white grunt) & $22.45(13.34)$ & $\mathrm{R}, \mathrm{N}$ \\
\hline \multicolumn{3}{|l|}{ Sciaenidae: drums } \\
\hline Equetus acuminatus (high-hat) & $0.02(0.06)$ & $\mathrm{R}$ \\
\hline \multicolumn{3}{|l|}{ Mullidae: goatfishes } \\
\hline Mulloidichthys martinicus (yellow goatfish) & $0.01(0.06)$ & $T, x$ \\
\hline Pseudupeneus maculatus (spotted goatfish) & $0.28(0.26)$ & $T, X$ \\
\hline \multicolumn{3}{|l|}{ Chaetodontıdae: butterflyfishes } \\
\hline Chaetodon capistratus (foureye butterflyfish) & $010(0.17)$ & $\mathrm{R}$ \\
\hline C. striatus (banded butterflyfish) & $0.02(0.06)$ & $\mathrm{R}$ \\
\hline \multicolumn{3}{|l|}{ Pomacanthidae: angelfishes } \\
\hline Holacanthus ciliaris (queen angelfish) & $1.67(0.84)$ & $R, N$ \\
\hline H. tricolor (rock beauty) & $0.74(0.74)$ & $\mathrm{R}$ \\
\hline Pomacanthus arcuatus (gray angelfish) & $0.02(0.06)$ & $R, N$ \\
\hline P. paru (French angelfish) & $0.05(0.12)$ & $R, N$ \\
\hline
\end{tabular}


Table 1 (continued)

\begin{tabular}{|c|c|c|}
\hline Species & Abundance & Classification \\
\hline \multicolumn{3}{|l|}{ Pomacentridae: damselfıshes } \\
\hline Chromis cyanea (blue chromis) & $3.00(3.88)$ & $R, N$ \\
\hline C. multilineata (brown chromis) & $0.83(0.42)$ & $R, N$ \\
\hline Pomacentrus diencaeus (longfin damselfish) & $0.07(0.17)$ & $\mathrm{R}$ \\
\hline P. dorsopunicans (dusky damselfish) & $0.02(0.06)$ & $\mathrm{R}$ \\
\hline P. leucostictus (beaugregory) & $0.86(0.76)$ & $\mathrm{R}, \mathrm{N}$ \\
\hline P. partitus (bicolor damselfish) & $1.10(0.82)$ & $R, N$ \\
\hline P. planifrons (threespot damselfish) & $0.01(0.08)$ & $\mathrm{R}$ \\
\hline P. variabilis (cocoa damselfish) & $0.38(0.25)$ & $\mathrm{R}, \mathrm{N}$ \\
\hline \multicolumn{3}{|l|}{ Labridae: wrasses } \\
\hline Bodianus rufus (Spanish hogfish) & $0.01(0.12)$ & $\mathrm{T}$ \\
\hline Halichoeres bivittatus (slippery dick) & $3.95(2.02)$ & $T, X, N$ \\
\hline H. garnoti (yellowhead wrasse) & $0.33(0.23)$ & $T, X, N$ \\
\hline H. maculipinna (clown wrasse) & $0.40(0.45)$ & $T, \curvearrowright$ \\
\hline H. pictus (painted wrasse) & $1.62(2.03)$ & $R, N$ \\
\hline H. poeyı (blackear wrasse) & $0.24(0.38)$ & $\mathrm{T}$ \\
\hline H. radiatus (puddingwife) & $0.17(0.21)$ & $T, N$ \\
\hline Hemipteronotus novacula (pearly razorfish) & & $\mathrm{x}$ \\
\hline Thalassoma bifasciatum (bluehead wrasse) & $6.64(1.10)$ & $\mathrm{R}, \mathrm{N}$ \\
\hline \multicolumn{3}{|l|}{ Scaridae: parrotfishes } \\
\hline Sparisoma aurofrenatum (redband parrotfish) & $0.05(0.12)$ & $\mathrm{T}$ \\
\hline S. chrysopterum (redtail parrotfish) & $0.23(0.30)$ & $\mathrm{T}$ \\
\hline S. viride (stoplight parrotfish) & $0.05(0.15)$ & $\mathrm{T}$ \\
\hline \multicolumn{3}{|l|}{ Sphyraenidae: barracudas } \\
\hline Sphyraena barracuda (great barracuda) & & $\mathrm{x}$ \\
\hline \multicolumn{3}{|l|}{ Clinidae: clinids } \\
\hline Malacoctenus macropus (rosy blenny) & $0.14(0.18)$ & $\mathrm{R}$ \\
\hline M. triangulatus (saddled blenny) & $0.05(0.12)$ & $\mathrm{R}$ \\
\hline \multicolumn{3}{|l|}{ Blenniidae: combtooth blennies } \\
\hline Entomacrodus nigricans (pearl blenny) & $0.05(0.12)$ & $\mathrm{R}$ \\
\hline Ophioblennius atlanticus (redlip blenny) & $0.07(0.17)$ & $\mathrm{R}$ \\
\hline \multicolumn{3}{|l|}{ Gobildae: gobies } \\
\hline Coryphopterus glaucofraenum (bridled goby) & $0.31(0.21)$ & $\mathrm{R}, \mathrm{N}$ \\
\hline Goblosoma evelynae (sharknose goby) & $0.07(0.17)$ & $\mathrm{R}, \mathrm{N}$ \\
\hline \multicolumn{3}{|l|}{ Acanthuridae: surgeonfishes } \\
\hline Acanthurus bahianus (ocean surgeon) & $3.55(1.53)$ & $\mathrm{T}, \mathrm{X}$ \\
\hline A. chirurgus (doctorfish) & $2.62(1.32)$ & $T, X$ \\
\hline A. coeruleus (blue tang) & $1.02(0.69)$ & $\mathrm{T}, \mathrm{X}$ \\
\hline \multicolumn{3}{|l|}{ Scombridae: mackerels } \\
\hline Scomberomorus regalis (cero) & & $\mathrm{x}$ \\
\hline \multicolumn{3}{|l|}{ Bothidae: lefteye flounders } \\
\hline Bothus lunatus (peacock flounder) & $0.05(0.07)$ & $T, X$ \\
\hline \multicolumn{3}{|l|}{ Balistidae: leatherjackets } \\
\hline Balistes vetula (queen triggerfish) & $0.01(0.14)$ & $\mathrm{R}$ \\
\hline Cantherhines pullus (orangespotted filefish) & $0.07(0.12)$ & $\mathrm{R}$ \\
\hline \multicolumn{3}{|l|}{ Tetraodontidae: puffers } \\
\hline Canthigaster rostrata (sharpnose puffer) & $2.00(0.33)$ & $\mathrm{R}, \mathrm{N}$ \\
\hline Sphoeroides spengleri (bandtail puffer) & $0.02(0.06)$ & $\mathrm{T}$ \\
\hline
\end{tabular}

Recruitment of other abundant species during this study was also variable (Fig. 3). Blackbar soldierfish Myripristis jacobus and surgeonfishes Acanthurus spp. showed peak recruitment during January to March. with the surgeonfishes having a protracted recruitment season. Damselfishes (Pomacentridae) and wrasses (Labridae) recruited mostly during May to June.

Variation in relative abundances of dominant species among different reefs yielded additional evidence of the importance of postrecruitment interactions on assemblage structure. Of the 4 most abundant species 


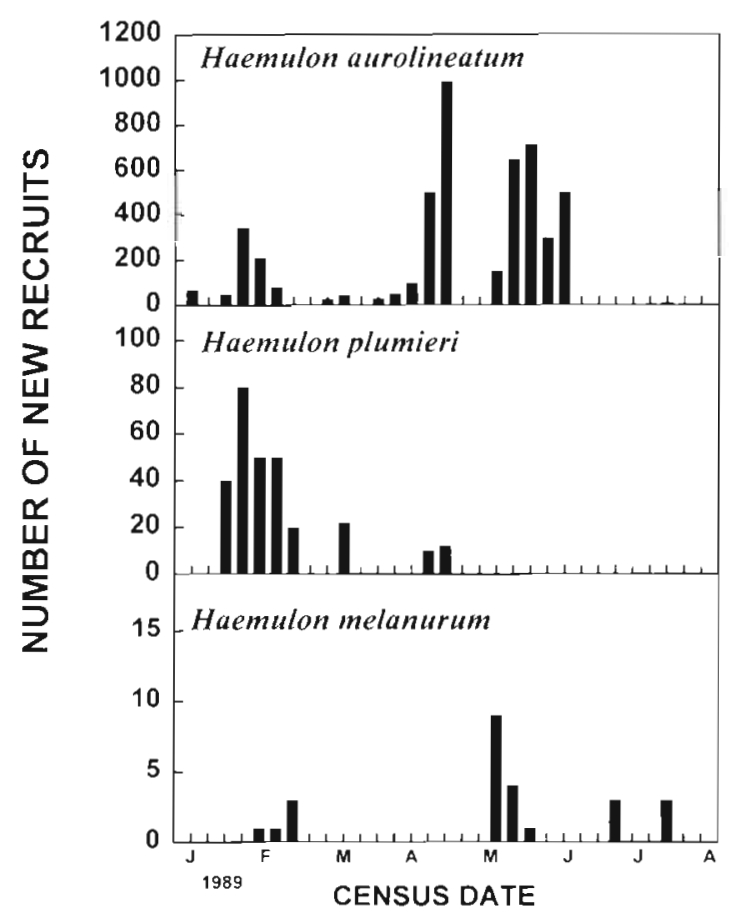

Fig. 2. Recruit abundance of the 3 dominant grunt species observed on experimental reefs in 1989 (total numbers of recruits summed over 12 reefs for each census date)

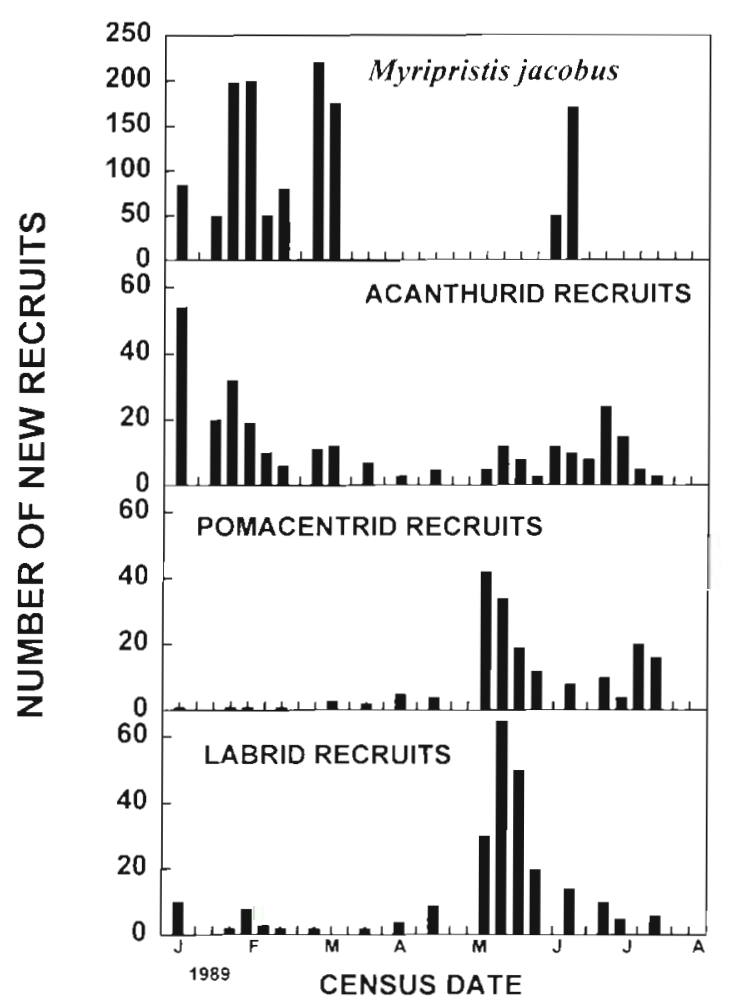

Fig. 3. Recruit abundance of dominant taxa (excluding grunts) observed on experimental reefs in 1989 (total numbers of recruits summed over 12 reefs for each census date)

\section{A. PREDATOR-REMOVAL REEFS}

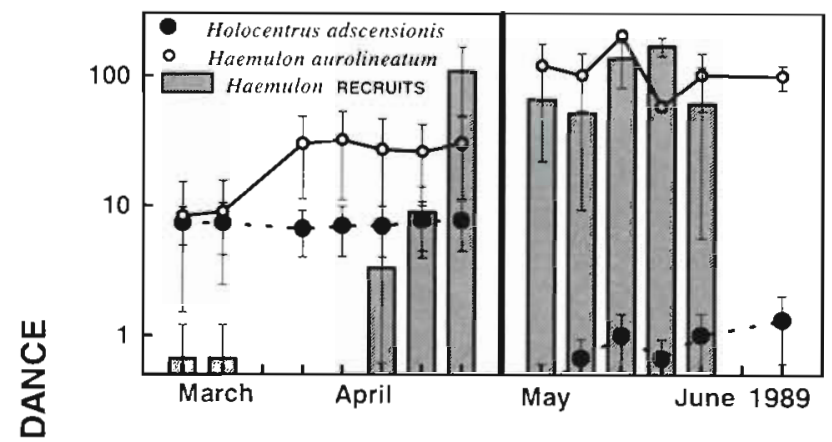

B. CONTROL REEFS

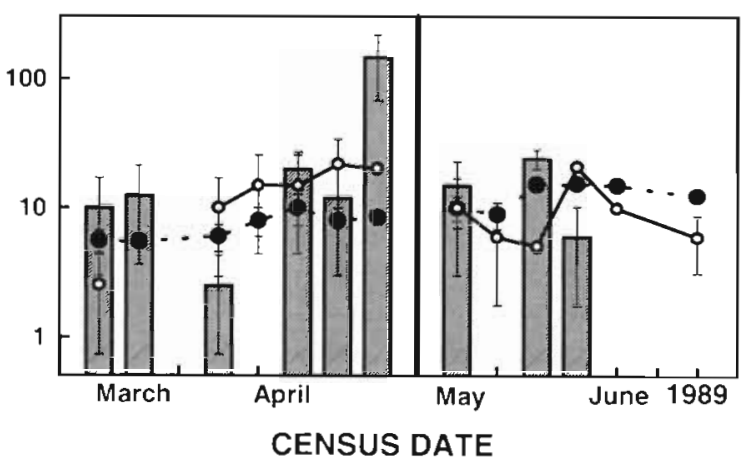

Fig. 4. Expt 1. Effect of Holocentrus adscensionis removals during peak recruitment of grunts. Mean number ( \pm SE) of individuals per species on $(A)$ manipulated reefs $(n=2)$ and $(B)$ control reefs $(n=3)$. Dark vertical line represents date of manipulation

present on these model reefs, 3 were grunts and 1 was the holocentrid Myripristis jacobus (Table 1). Although the abundance of each grunt species varied greatly among reefs, the rank order of abundance was consistent among reefs. The most abundant species was tomtate grunt Haemulon aurolineatum. Although small grunt recruits $(<1 \mathrm{~cm})$ were not identified to species during censuses, most small juveniles $(>2 \mathrm{~cm}$ ) were easily identified as $H$. aurolineatum. Individuals of this species formed loose aggregations above the reef and were consistently most distant from reef structure $(>0.5 \mathrm{~m})$, taking shelter only when a predator swam near the reef. The second most abundant grunt was usually $H$. plumieri, which was the grunt species most closely associated with reef structure. Small juveniles $(<3 \mathrm{~cm})$ were frequently observed schooling above structure with or near individuals of $H$. aurolineatum. Larger individuals $(>3 \mathrm{~cm}$ ) were most often observed around the base or within the structure of the reef. The third most abundant grunt was normally $H$. melanurum, which appeared intermediate in their affinity for substrate. Although small juveniles were frequently observed schooling with other small grunts above the 
substrate, they tended to form monospecific groups circling close to the substrate and entering the structure when a predator swam near the reef.

Individuals of the holocentrid Myripristis jacobus had the greatest affinity for reef structure of any species observed during these experiments. This species was rarely observed above or away from reefs during daylight. On occasions before the experiments when preliminary test reefs were moved from one site to another, individuals of $M$. jacobus would closely aggregate around the remaining piece of structure after most other species had fled. Abundance of postlarval recruits of grunts did not appear to be affected by increased abundance of $M$. jacobus. This is probably due to the general greater abundance of Haemulon aurolineatum recruits and heterotypic schooling of postlarval grunts above the substrate away from the more benthic-oriented $M$. jacobus. The 2 species with the greatest affinity for the reef structure, $M$ jacobus and $H$. plumieri, demonstrated the greatest negative correlation of abundances (Pearson correlation coefficient: $-0.943, \mathrm{p}<0.01$ ). A similar pattern was observed between $M$. jacobus and Holocentrus adscensionis (Pearson correlation coefficient: -1.000 , $\mathrm{p}<0.01)$
The presence of other small predators (e.g. groupers or snappers) which colonized model reefs was not strongly correlated with abundances of recruits or prey species. Small groupers colonized in low abundance (1 to 3 individuals) on model reefs. Juvenile yellowtail snapper Ocyurus chrysurus were occasionally common on reefs but had low reef fidelity. Manipulations of these species on other reefs sets did not yield negative effects on abundances of recruits or prey species

\section{Effects of predator manipulations}

\section{Expt 1}

During peak recruitment in May 1989, removal of the predatory Holocentrus adscensionis had a significant effect on mean abundance of postlarval grunt recruits (Fig. 4). The manipulated reefs had a significantly greater number of grunt recruits compared to controls after the removals (Table 2), even though there were no significant differences before the removals

Recruits of other species, such as the frequently numerous blue chromis Chromis cyanea and bluehead

Table 2. Comparison of number of recruits between expenmental reefs with Holocentrus adcensionis removal and control reefs for 2 manupulations. Expt 1 was conducted during a recruitment event ( $n=2$ for removal and $n=3$ for control reefs). Expt 2 was conducted following a recruitment event ( $n=3$ for removal and $n=2$ for control reefs). Abundance data are mean number of recruits per treatment (mean of 4 consecutive censuses per reef) before and after removals. Standard errors are presented in parentheses. No signuficant difference was observed between removal and control reefs for either group before manipulations. Repeated measures ANOVA, removal versus control reefs

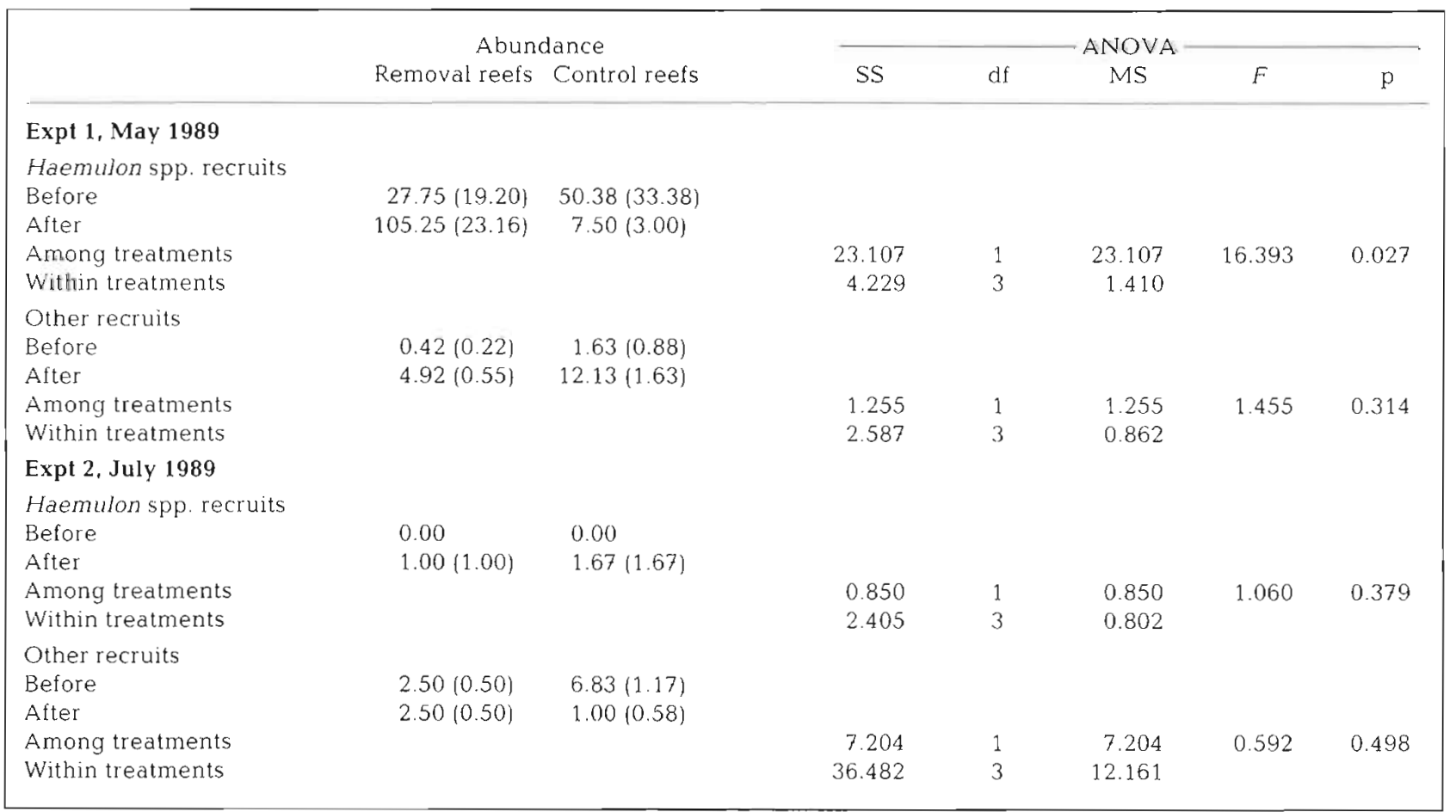




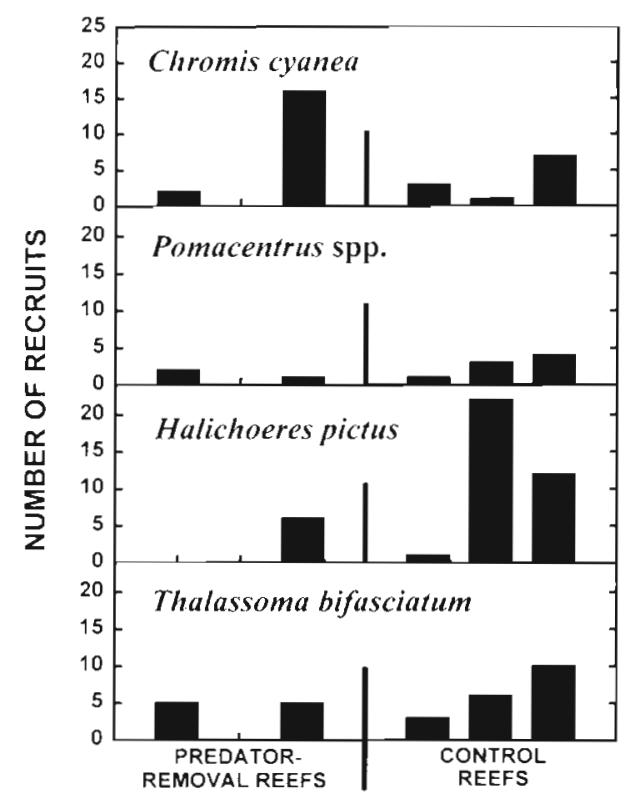

Fig. 5. Recruit abundance of dominant species (excluding grunts) observed following maximum recruitment peak (26 May 1989) on 6 expermental reefs. Individuals of Holocentrus adscensionis were removed on Reefs 1 and 4 on 3 May 1989 wrasse Thalassoma bifasciatum, were not more abundant on predator-removal reefs. In fact, recruitment of several species was quite variable among reefs (Fig. 5). Survivorship and/or persistence of larger juveniles of these species was low.

A large increase in larger individuals of tomtate grunt Haemulon aurolineatum was observed on reefs following removal of squirrelfishes (Table 3), and the differences between treatment and control reefs were significant. This was not observed for the other 2 most abundant grunt species, $H$. plumieri and $H$. melanurum.

Removal of Holocentrus adscensionis had a signficant effect on the mean abundance of larger resident fishes (excluding transients and recruits) (Fig 6, Table 3). Mean number of species showed a non-significant increase on removal reefs compared to the uniform number of species observed on control reefs (Fig. 6).

\section{Expt 2}

During the second Holocentrus adscensionis removal period, following the peak of the grunt recruitment season, the number of new grunt recruits was

Table 3. Comparison of number of fish of numerically dominant species and all resident fishes combined between model reefs with Holocentrus adscensionis removal and control reefs for 2 experiments. Expt 1 was conducted during a recruitment event. Expt 2 was conducted following a recruitment event. Data are mean number of fish per treatment (mean of 4 consecutive censuses per reef) before and after removals. Standard errors are presented in parentheses. $t$-tests were conducted on the differences between the mean abundance of fishes on each reef for 4 censuses before manipulations and 4 censuses after manipulations

\begin{tabular}{|c|c|c|c|c|}
\hline & \multicolumn{2}{|c|}{ Expt 1} & \multicolumn{2}{|c|}{ Expt 2} \\
\hline & $\begin{array}{c}\text { Removal reefs } \\
n=2\end{array}$ & $\begin{array}{c}\text { Control reefs } \\
n=3\end{array}$ & $\begin{array}{c}\text { Removal reefs } \\
n=3\end{array}$ & $\begin{array}{c}\text { Control reefs } \\
n=2\end{array}$ \\
\hline \multicolumn{5}{|c|}{ Haemulon aurolineatum } \\
\hline Before & $24.00(19.44)$ & $16.25(6.25)$ & $56.25(12.75)$ & $92.50(18.09)$ \\
\hline After & $101.25(13.94)$ & $8.25(2.25)$ & $66.00(6.00)$ & $20.67(11.35)$ \\
\hline Difference & 77.25 & 2.00 & 9.75 & -71.83 \\
\hline t-test & $t=-9.635$ & $p=0.002$ & $t=-7.683$ & $p=0.005$ \\
\hline \multicolumn{5}{|l|}{ H. plumieri } \\
\hline Before & $32.42(5.93)$ & $43.63(5.88)$ & $45.00(9.00)$ & $35.67(3.22)$ \\
\hline After & $13.67(2.35)$ & $31.75(3.25)$ & $58.00(12.00)$ & $14.00(2.65)$ \\
\hline Difference & -18.75 & -11.88 & 13.00 & -1.67 \\
\hline t-test & $t=-2.114$ & $p=0.125$ & $t=4.902$ & $p=0.016$ \\
\hline \multicolumn{5}{|c|}{ H. melanurum } \\
\hline Before & $9.25(5.11)$ & $11.38(8.38)$ & $23.75(12.75)$ & $12.17(7.30)$ \\
\hline After & $4.00(1.52)$ & $16.63(9.88)$ & $26.00(11.00)$ & $11.33(6.88)$ \\
\hline Difference & -5.25 & 5.25 & 2.25 & -0.83 \\
\hline$t$-test & $t=0.777$ & $\mathrm{p}=0.494$ & $t=-1.516$ & $p=0.227$ \\
\hline \multicolumn{5}{|c|}{ Resident fishes } \\
\hline Before & $188.92(53.26)$ & $1.12 .25(11.25)$ & $139.50(5.00)$ & $178.17(11.13)$ \\
\hline After & $288.75(29.92)$ & $122.25(9.25)$ & $149.50(0.50)$ & $107.00(16.82)$ \\
\hline Difference & 99.83 & 10.00 & 10.00 & -71.17 \\
\hline$t$-test & $t=5.363$ & $p=0.011$ & $t=3.099$ & $p=0.053$ \\
\hline
\end{tabular}




\section{A. PREDATOR-REMOVAL REEFS}

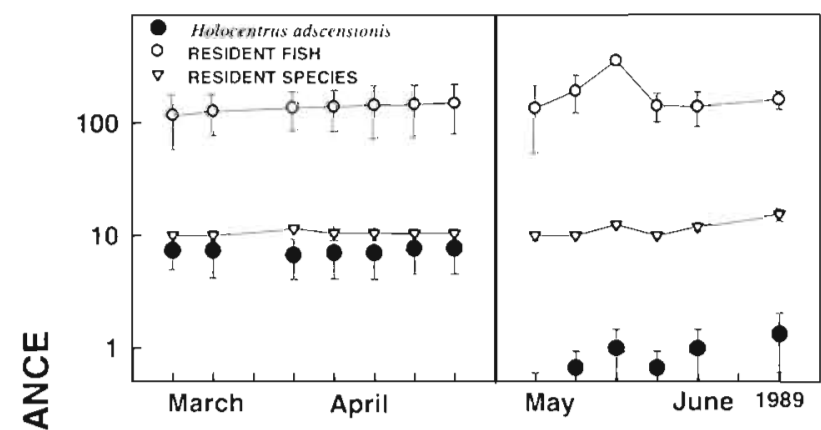

B. CONTROL REEFS

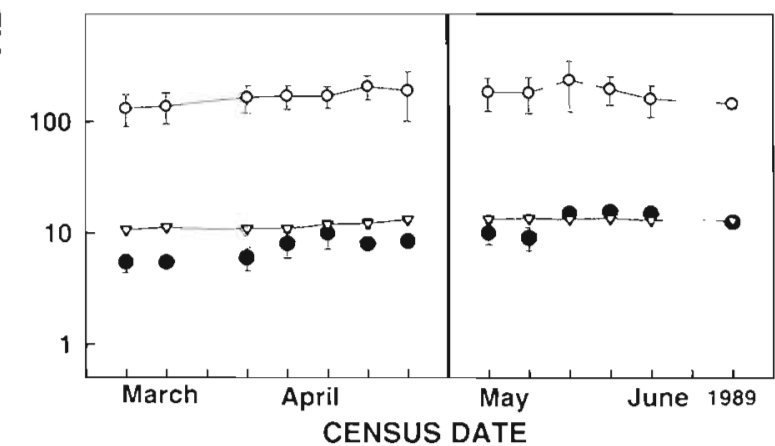

Fig. 6. Expt 1. Effect of Holocentrus adscensionis removals on the abundance and number of species of juvenile and adult resident fishes larger than $2 \mathrm{~cm}$ TL on (A) manupulated reefs $(n=3)$ and $(B)$ control reefs $(n=2)$. Dark vertical line represents date of manipulation

very low (mean number per census during July and August $=0.3$ compared to May and June $=275.3$ ) and no apparent increase was noted on predator-removal reefs (Fig. 7, Table 2). However, the number of larger juvenile grunts ( 2 to $5 \mathrm{~cm}$ TL) was greater on the manipulated reefs relative to controls (Fig. 7). These differences were significant for Haemulon aurolineatum and $H$. plumieri (Table 3 ).

\section{DISCUSSION}

\section{Species interactions and postlarval recruitment}

Previous studies of interactions between newly settled recruits and established juveniles or adults have suggested the importance of both active exclusion and facilitation of new recruits (Sale et al. 1980, Williams 1980, Sweatman 1983, 1985, Jones 1987, Booth 1991). Although predation has received less attention, recent studies have presented evidence for the importance of predation in structuring coral reef fish assemblages (Doherty \& Sale 1985, Shulman 1985, Shulman \&
Ogden 1987, Hixon \& Beets 1989, 1993, Caley 1993, Carr \& Hixon 1995).

During this investigation, the presence of squirrelfish Holocentrus adscensionis reduced the local abundance of grunt recruits and juveniles. In the first experiment, conducted during a large pulse of settlement, greater numbers of $H$. adscensionis had a significant negative effect on the abundance of grunt recruits, larger juvenile tomtate Haemulon aurolineatum, and resident fishes. In the second experiment, conducted following the peak recruitment period, removal of $H$, adscensionis again resulted in a significantly greater number of juvenile grunts on predatorremoval reefs compared to control reefs.

In the present study, removal of a single predator, Holocentrus adscensionis, had a negative effect on abundances of grunts and resident fishes. Removal of an entire guild of piscivores should certainly have an effect on the abundance and/or species richness of non-piscivorous fishes if predators are important in the system. Hixon \& Beets $(1989,1993)$ observed significant negative relationships among reefs between piscivore abundance and maximum number of prey fish

\section{A. PREDATOR-REMOVAL REEFS}

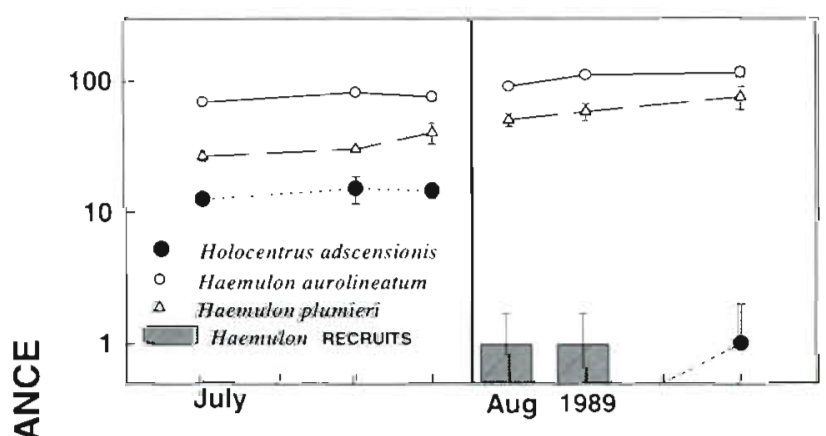

B. CONTROL REEFS

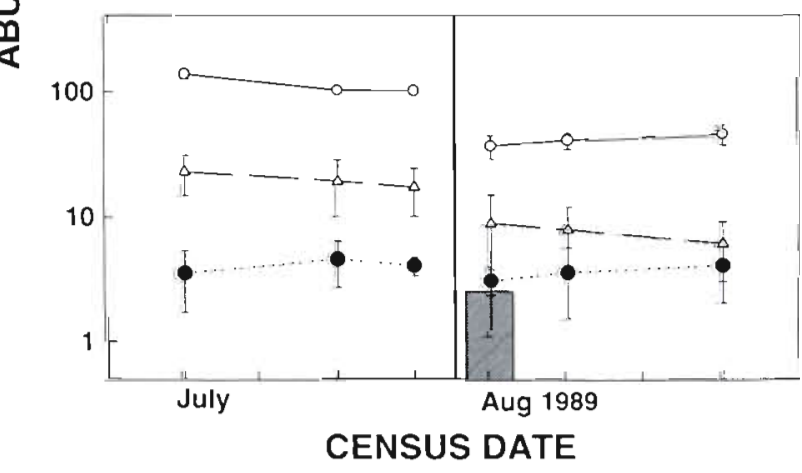

Fig. 7. Expt 2. Effect of Holocentrus adscensionis removals following peak recruitment of grunts. Mean number of individuals per species on (A) manipulated reefs $(n=2)$ and (B) control reefs $(\mathrm{n}=3)$. Dark vertical line represents date of manipulation 
and prey species. In a recent study in the Bahamas, Carr \& Hixon (1995) demonstrated that resident predator removals on experimental reefs had significant effects on the survivorship of newly settled recruits of damselfish Chromis cyanea and wrasse Halichoeres pictus. In a predator removal study conducted on the Great Barrier Reef, Caley (1993) observed generally greater species richness and total abundance of newly recruited, non-piscivorous fishes following removals of all piscivorous fishes on experimental reefs; however, most of these pattern were non-significant.

The presence of recently settled predators (Lutjanus mahogani or L. buccanella) previously has been correlated with decreased settlement of prey fish (Haemulon spp.; Shulman et al. 1983, see also Sweatman 1993). During the present investigation, the presence of recently colonized individuals of predatory grouper and snapper species had no observed effect on the recruitment or abundance of grunts or other species. Shulman et al. (1983) observed inhibition of grunt set. tlement when recently settled snappers were present. The large recruitment of grunts observed during the present investigation may have overwhelmed the effect of a few small predatory groupers and snappers (1 to 3 ) on these small reefs.

\section{Species interactions and assemblage structure}

Several authors have concluded that larval supply is the primary factor determining population and assemblage structure of coral reef fishes (Doherty \& Williams 1988, Doherty 1991, Doherty \& Fowler 1994). Although acknowledgment has been made of the need for additional research on predator-prey relationships, much less importance has been given to postrecruitment mechanisms. Alternatively, Hixon (1991) and Jones (1991) reviewed evidence supporting the importance of predation on coral reef fish assemblage structure, hypothesizing that a combination of pre- and postsettlement mortality due to predation may commonly limit population sizes below levels where competition occurs

The results of this study support the importance of post-settlement predation on local population and assemblage structure of coral reef fishes, at least on a small spatial scale. High densities of Holocentrus adscensionis resulted in lower densities of grunts. Critical to the understanding of post-settlement processes, such as predation, are the effects at various spatial scales and the manner in which different processes interact at those scales (Jones 1991, Sale 1991). Small, local patches may appear to be structured by the abundance of superior competitors or the local effects of predators. However, differential recruitment or other density-independent effects may allow for a shift in the established dominance over time. On larger spatial and temporal scales, numerous factors, such as larval supply, subsequent species interactions, reef characteristics (structure, location, isolation, etc.), should allow for a variety of resulting assemblage structures in patches within a large reef tract (Hixon \& Beets 1993).

In conclusion, the squirrelfish-grunt interactions observed during this experiment support the importance of predation in structuring coral reef fish assemblages. Predation was probably not the only mechanism responsible for the patterns observed during this study. Postlarval avoidance of settling on reefs with predators, and juvenile emigration from reefs with high or increasing predator abundance may have contributed to the observed patterns. Regardless, the threat of predation in such cases would be as effective as direct predation in influencing the local abundance and assemblage structure of coral reef fishes.

Acknowledgements. This research was possible due to the fleld assistance of the staff of the U.S. Virgin Islands Division of Fish and Wildifie, especially my field assistant, Alan Friedlander. I owe special thanks to Gene Helfman for his assistance and guidance throughout this study. Mark Hixon provided great assistance in design and review. Additional support and assistance was provided by R. Boulon, J. LaPlace, and $L$. Muehlstein. This manuscript was greatly enhanced by comments from M. Carr, G. Helfman, M. Hixon, and 2 anonymous reviewers. Many thanks go to $\mathrm{H}$. Wouk for impressive comprehension and eloquent description of local conditions. Support for thus research was provided from the U.S. Fish and Wildlife Service Sport Fisheries Restoration Funds to the U.S. Virgin Islands and the University of Georgıa

\section{LITERATURE CITED}

Beets JP (1991) Aspects of recruitment and assemblage structure of Caribbean coral reef fishes. PhD dissertation, University of Georgia

Bohnsack JA (1982) Effects of piscivorous predator removal on coral reef fish community structure. In: Cailliet GM. Simenstad CA (eds) Fish food habit studies. Washington Sea Grant Publication, Seattle, p 258-267

Booth DJ (1991) The effects of sampling frequency on estimates of recruitment of the domino damselfish Dascyllus albisella Gill. J Exp Mar Biol Ecol 145:149-159

Caley MJ (1993) Predation, recruitment and the dynamics of communities of coral-reef fishes. Mar Biol 117:33-43

Carr MH, Hixon MA (1995) Predation effects on early postsettlement survivorship of coral-reef fishes. Mar Ecol Prog Ser $124: 31-42$

Connell JH (1983) On the prevalence and relative importance of interspecific competition: evidence from field experiments. Am Nat 122:661-696

Doherty PJ (1983) Tropical territorial damselfishes: is density limited by aggression or recruitment? Ecology 64:176-190

Doherty PJ (1991) Spatial and temporal patterns in recruitment. In: Sale PF (ed) The ecology of fishes on coral reefs. Academlc Press, San Diego, p 261-293 
Doherty P, Fowler T (1994) An empirical test of recruitment limitation in a coral reef fish. Science 263:935-939

Doherty PJ, Sale PF (1985) Predation on juvenile coraI reef fishes: an exclusion experiment. Coral Reefs 4:225-234

Doherty PJ, Williams DM (1988) The replenishment of coral reef fish populations. Oceanogr Mar Biol Annu Rev 26 : $487-551$

Forrester GE (1990) Factors influencing the juvenile demography of a coral reef tish. Ecology 71:1666-1681

Forrester GE (1995) Strong density-dependent survival and recruitment regulate the abundance of a coral reef fish. Oecologia 103:275-282

Gladfelter WB, Johnson WS (1983) Feeding niche separation in a guild of tropical reef fishes (Holocentridae). Ecology 64:552-563

Hixon MA (1991) Predation as a process structuring coral reef fish communuties. In: Sale PF (ed) The ecology of fishes on coral reefs. Academic Press, San Diego, p 475-508

Hixon MA, Beets JP (1989) Shelter characteristics and Caribbean fish assemblages: experiments with artificjal reefs. Bull Mar Sci 44:666-680

Hixon MA, Beets JP (1993) Predation, prey refuges, and the structure of coral-reef fish assemblages. Ecol Monogr 63: $77-101$

Jones GP (1987) Some interactions between residents and recruits in two coral reef fishes. J Exp Mar Bıol Ecol 114 $169-182$

Jones GP (1990) The importance of recruitment to the dynamics of a coral reef tish population. Ecology 71:1691-1698

Jones GP (1991) Post-recruitment processes in the ecology of coral reef fish populations: a multifactorial perspective. In: Sale PF (ed) The ecology of fishes on coral reefs. Academic Press, San Diego, p 294-330

Kerfoot WC, Sih A (eds) (1987) Predation: direct and indirect impacts on aquatic communities. University Press of New England, Hanover, NH

Mapstone BD. Fowler AJ (1988) Recruitment and the structure of assemblages of fish on coral reefs. Trends Ecol \& Evol 3:72-77

Randall JE (1967) Food habits of reef fishes of the West Indies Stud Trop Oceanogr Miami 5:665-847

Robins CR, Bailey RM, Bond CE, Brooker JR, Lachnerm EA, Lea RN, Scott WB (1991) Common and scientific names of fishes from the United States and Canada, 5th edn. American Fisheries Society Spec Publ 20

Ross ST (1986) Resource partitioning in fish assemblages: a review of field studies. Copeia 1986:352-388

Sale PF (1991) Reef fish communities; open non-equilibrial systems. In: Sale PF (ed) The ecology of fishes on coral reefs. Academic Press, San Diego, p 564-598

Sale PF, Doherty PJ, Douglas WA (1980) Juvenile recruitment strategies and coexistence of territorial pomacentrids. Bull Mar Sci 30:147-158

Sale PF, Douglas WA (1981) Precision and accuracy of visual

This article was submitted to the editor census technique for fish assemblages on coral patch reefs. Environ Biol Fishes 6:333-339

Sale PF, Douglas WA (1984) Temporal varlability in the community structure of fish on coral patch reefs and the relation of community structure to reef structure. Ecology 65: $409-422$

Shpigel M. Fishelson L (1991) Experimental removal of piscivorous groupers of the genus Cephalophols (Serranidae) from coral habitats in the Gulf of Aqaba (Red Sea). Environ Biol Fishes 31:131-138

Shulman MJ (1985) Recruitment of coral reef fishes: effects of distribution of predators and shelter. Ecology 66: 1056- 1066

Shulman MJ, Ogden JC (1987) What controls tropical reef fish populations: recruitment or benthic mortality? An example in the Caribbean reef fish Haemulon flavolineatum. Mar Ecol Prog Ser 39:233-242

Shulman MJ, Ogden JC, Ebersole JP, McFarland WN, Miller SL. Wolf NG (1983) Priority effects in the recruitment of Juvenile coral reef fishes. Ecology 64:1508-1513

Sih A, Crowley P, McPeek M, Petranka J, Strohmeier K (1985) Predation, competıtion, and prey communities: a review of field experiments. Annu Rev Ecol Syst 16:269-311

Sousa WP (1984) The role of disturbance in natural communities. Annu Rev Ecol Syst 15:353-391

Stimson J, Blum S, Brock R (1982) An experimental study of the influence of muraenid eels on reef fish sizes and abundance. Unw Hawai Sea Grant Quarterly 4:1-6

Strong D, Simberloff D. Abele LG, Thistle AB (eds) (1984) Ecological communities: conceptual issues and the evidence. Princeton University Press, Princeton, NJ

Sweatman HPA (1983) Influence of conspecifics on choice of settlement sites by larvae of two pomacentrid fishes (Dascyllus aruanus and D. reticulatus) on coral reefs. Mar Biol $75: 225-229$

Sweatman HPA (1985) The influence of adults of some coral reef fishes on larval recruitment. Ecol Monogr 55:469-485

Sweatman HPA (1993) Tropical snapper (Lutjanidae) that is piscivorous at settlement. Copeia 1993:1137-1139

Victor BC (1986) Larval settlement and juvenule mortality in a recruitment-limited coral reef fish population. Ecol Monogr 56:145-160

Warner RR, Hughes TP 1988 The population dynamics of reef fishes. Proc 6th Int Symp Coral Reefs 1:149-155

Wilkinson L (1990) SYSTAT the system for statistıcs. Systat, Inc, Evanston, IL

Williams DM (1980) Dynamics of the pomacentrid community on small patch reefs in One Tree Lagoon (Great Barrier Reef). Bull Mar Sci 30:159-170

Williams DM (1991) Patterns and processes in the distribution of coral reef fishes. In: Sale PF (ed) The ecology of fishes on coral reefs. Academic Press, San Diego, p 437-474

Winer FJ (1971) Statistical principals in experimental design, 2nd edn. McGraw-Hill, New York

Manuscript first received: May 5, 1996

Revised version accepted: December 4, 1996 